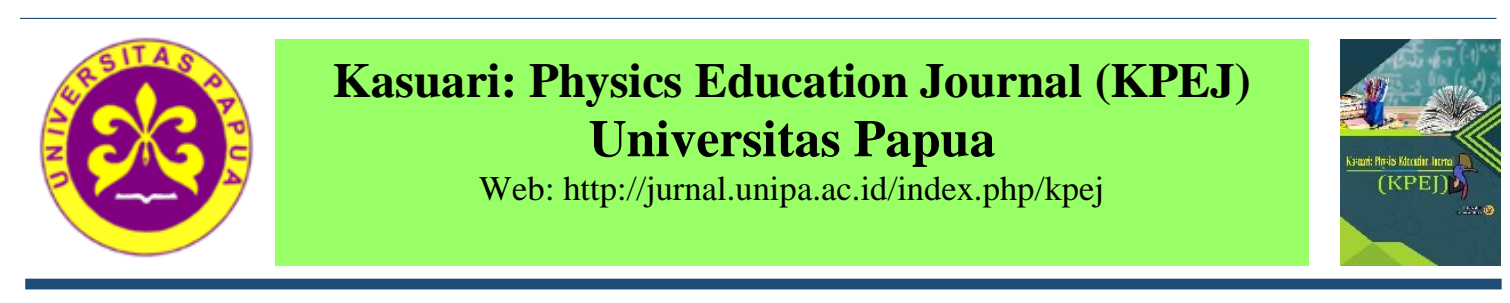

\title{
Ability Media Robotics (Robot Soccer) in Fostering the Learning Interest of Students in the Subjects of Physics
}

\author{
Indica Yona Okyranida, Dandan Luhur Saraswati", \& Neng Nenden Mulyaningsih \\ Pendidikan Fisika, Fakultas Matematika dan IPA, Universitas Indraprasta PGRI \\ *dandanluhur@gmail.com
}

\begin{abstract}
In this research was quantitative research to know the increase of interest in student learning by using robotic media. Robotic media used in this study uses the robot soccer. The design of these studies using experimentation. Interest in student learning data taken using question form interest in learning. This dalampenelitian data processing using trial T or t-test were analyzed using SPSS. The results showed that there was an increased interest in learning of students in the subjects of physics using media Robotics (robot soccer) with the acquisition value of the pretest of 66.81 postest and value of 77.05 .
\end{abstract}

Keywords: Robotics, Robot Soccer, and Interest in Learning Physics

\section{Kemampuan Media Robotik (Robot Soccer) dalam Menumbuhkan Minat Belajar Peserta didik pada Mata Pelajaran Fisika}

\begin{abstract}
Abstrak: Penelitian ini merupakan penelitian kuantitatif untuk mengetahui peningkatan minat belajar peserta didik dengan menggunakan media robotik. Media robotik yang digunakan dalam penelitian ini menggunakan robot soccer. Desain penelitian ini menggunakan eksperimen. Data minat belajar peserta didik diambil menggunakan angket minat belajar. Pengolahan data dalampenelitian ini menggunakan Uji-T atau t-test yang dianalisis menggunakan SPSS. Hasil penelitian menunjukkan bahwa ada peningkatan minat belajar peserta didik pada mata pelajaran fisika menggunakan media robotik (robot soccer) dengan perolehan nilai pretest sebesar 66,81 dan nilai postest sebesar 77,05.
\end{abstract}

Kata kunci: Robotik, Robot Soccer, dan Minat Belajar Fisika

\section{PENDAHULUAN}

Dampak signifikan yang dirasakan pada era 4.0 adalah perkembangan informasi dan teknologi dan tak terkecuali dalam bidang pendidikan (Ramansyah \& Brian, 2018). Segala aspek yang tersentuk dari berkembangnya teknologi ini salah satunya adalah bidang elektronika yaitu robotika. Robot merupakan alat yang diciptakan untuk memudahkan pekerjaan manusia. Robot selama ini kita kenal adalah sebuah mesin berbentuk manusia maupun hewan yang dapat berbicara dan bergerak. Robot merupakan serangkaian sistem elektronik buatan mekanik maupun virtual yang biasanya mesin elektro-mekanis ini dipandu oleh suatu program baik Komputer maupun sirkuit elektronik (Ardiansyah, 2019).

Salah satu sarana penunjang dalam proses pembelajaran adalah media pembelajaran (Dewi, Nyeneng, \& Suana, 2019); (Putri \& Saraswati, 2018). Dalam memanfaatkan media pembelajaran ini juga harus memperhatikan faktor karakteristik media yang digunakan serta disesukan dengan materi belajar (Efendi, 2018). Tuntutan teknologi yang semakin besar menuntut guru untuk terus berinovasi dalam pembelajaran. Bagaimana seorang guru dalam meningkatkan kompetensi yang dimiliki untuk membuat proses 
pembelajaran menjadi lebih menarik dan inovatif serta memberikan pengalaman belajar secara langsung sangatlah penting (Putra, Sigalingging, \& Saraswati, 2018); (Saraswati, 2018); (Astuti \& Sugianti, 2019); (Widyaningsih \& Yusuf, 2018).

Berdasarkan hasil observasi yang dilakukan dalam proses pembelajaran fisika di SMK Tritura ditemukan beberapa kendala diantaranya adalah kurangnya minat peserta didik untuk belajar, minimnya media yang digunakan dalam proses pembelajaran, serta terbatasnya kemampuan pendidik dalam mengembangkan sarana dan prasaran yang ada. Oleh karena itu peneliti sangat tertarik untuk mengemas proses pembelajaran fisika yang dapat menarik minat belajar peserta didik dengan memanfaatkan sarana dan prasarana yang ada yaitu menggunakan robot soccer. Robot soccer adalah salah satu jenis aplikasi untuk teknik navigasi yang dapat bergerak sesuai perintah yang diberikan dari remot kontrol (Yulianto \& Handoyo, 2012). Untuk aplikasi dalam sepak bola pergerakan robot dapat digunakan untuk menggiring bola dan menendang bola. Dengan menggunakan robot soccer ini peserta didik diberi pengenalan dan pemahaman dalam pembelajaran fisika mengenai komponen-komponen elektronika yang dapat dirakit menjadi sistem dalam robot.

Minat belajar membentuk sikap akademik tertentu yang bersifat sangat pribadi pada setiap peserta didik. Oleh karena itu, minat belajar harus ditumbuhkan sendiri oleh masing-masing peserta didik. Seseorang dikatakan memiliki ketertarikan untuk belajar ketika ia memiliki perasaan tertarik pada pelajaran tersebut (Nurhasanah \& Sobandi, 2016). Faktor eksternal hanya memperkuat dan menumbuhkan minat atau untuk memelihara minat yang telah dimiliki oleh individu (Loekmono, 2004). Minat berkaitan dengan nilai-nilai tertentu sehingga nilai-nilai dalam aktivitas belajar sangat bermanfaat untuk membangkitkan minat. Misalnya dalam memenuhi rasa ingin tahu mendapatkan gelar atau memperoleh pekerjaan, jika minat belajar telah didapatkan maka akan menumbuhkan konsentrasi atau kesungguhan dalam belajar (Sudarmono, 2014).

Minat tidak dibawa sejak lahir melainkan diperoleh dari lingkungan sekitar yang dapat menumbuhkan minat positif. Minat terhadap sesuatu dipelajari dan mempengaruhi belajar selanjutnya serta mempengaruhi penerimaan minat baru. Jadi, minat terhadap sesuatu merupakan hasil belajar dan membantu belajar selanjutnya walaupun minat terhadap sesuatu hal tidak merupakan hal yang hakiki untuk dapat mempelajari hal tersebut. Guru berperan dalam memotivasi peserta didik untuk menggali dan menumbuhkan minat belajar (Saraswati \& Ishafit, 2015).

\section{METODE PENELITIAN}

Penelitian dilakukan di SMK Tritura yang beralamatkan di Cilangkap, Tapos, Kota Depok, Jawa Barat. Populasi dari kelas X yang terdiri dari lima kelas. Penentuan sampel menggunakan teknik cluster random sampling dari lima kelas diambil dua kelas dengan jumlah peserta didik sebanyak 33 peserta didik kelas kontrol dan 34 peserta didik kelas eksperimen. Kelas untuk penelitian yaitu kelas X1 sebagai kelas kontrol menggunakan demonstrasi dan X2 sebagai kelas eksperimen, yang selanjutnya diberi treatmen pembelajaran menggunakan media robotik (robot soccer). Sebelum diberi pembelajaran menggunakan robotik peserta didik diberi pretes minat belajar menggunakan angket minat belajar untuk mengetahui hasil minat awal peserta didik. Adapun indikator minat dapat dilihat pada Tabel 1. Setelah itu, peserta didik diberi pembelajaran menggunakan media robotik (robot soccer). Di akhir pembelajaran peserta didik diberi angket posttest yang digunakan untuk mengetahui minat setelah pembelajaran. 
Tabel 1. Indikator minat peserta didik

\begin{tabular}{|c|c|c|c|}
\hline \multirow{2}{*}{ Variabel } & Indikator & \multicolumn{2}{|c|}{ Butir Soal } \\
\cline { 2 - 4 } & & Positif & Negatif \\
\hline Minat & Perasaan terhadap fisika & $2,9,14$ & $3,4,17$ \\
\cline { 2 - 4 } Peserta & Kesediaan untuk mencatat di kelas & $1,5,11,13$, & $15,16,18$ \\
\cline { 2 - 4 } didik & Kesadaran terhadap manfaat fisika & $6,7,8,19,20$ & 10,12 \\
\hline
\end{tabular}

Data diambil dari populasi yang terdistribusi normal dan homogen. Pengaruh treatmen dianalisis menggunakan statistik t-test. Hal tersebut bertujuan untuk mengetahui apakah terdapat perbedaan antara hasil pretest dan post test minat belajar fisika peserta didik. Jika terdapat perbedaan yang signifikan antara hasil minat belajar peserta didik tersebut, maka perlakuan yang diberikan berpengaruh secara signifikan.

\section{HASIL DAN PEMBAHASAN}

Pada penelitian ini data minat belajar diperoleh dari nilai angket peserta didik yang diberikan setelah proses belajar mengajar berlangsung. Sebaran nilai dari data minat belajar dari masing-masing kelas disajikan dalam Tabel 2.

Tabel 2. Deskripsi data minat belajar peserta didik

\begin{tabular}{|l|c|c|c|c|c|c|}
\hline Kelompok & $\begin{array}{c}\text { Jumlah } \\
\text { Data }\end{array}$ & $\begin{array}{c}\text { Nilai } \\
\text { Tertinggi }\end{array}$ & $\begin{array}{c}\text { Nilai } \\
\text { Terendah }\end{array}$ & Rata-rata & SD & Varians \\
\hline Kontrol & 33 & 80 & 55 & 66,81 & 8,27 & 62,068 \\
Eksprimen & 34 & 96 & 65 & 77,05 & 7,51 & 58,155 \\
\hline
\end{tabular}

Pada kelompok kontrol yang berjumlah 33 peserta didik diperoleh nilai tertinggi 80 dan nilai terendah 55 dari nilai tersebut menghasilkan rata-rata sebesar 66,81. Pada kelompok eksperimen yang berjumlah 34 peserta didik diperoleh nilai tertinggi sebesar 96 dan nilai terendah 65 dari nilai tersebut menghasilkan rata-rata sebesar 77,05. Nilai rata-rata minat belajar peserta didik pada kelompok eksperimen memiliki nilai lebih tinggi daripada peserta didik pada kelompok kontrol. Hal ini dapat diketahui dari nilai standar deviasi kelompok eksperimen lebih kecil daripada peserta didik kelompok kontrol. Standar deviasi merupakan jarak antara data dengan nilai rata-rata, sehingga semakin kecil nilai standar deviasi, maka nilai tersebut semakin dekat dengan nilai ratarata. Hal tersebut menunjukkan bahwa minat belajar kelompok eksperimen lebih baik daripada kelompok kontrol. Distribusi frekuensi minat belajar peserta didik pada masingmasing kelas disajikan pada Tabel 3.

Tabel 3. Hasil Minat Belajar Peserta didik

\begin{tabular}{|c|c|c|c|c|}
\hline Interval & \multicolumn{2}{|c|}{ Kontrol } & \multicolumn{2}{c|}{ Eksperimen } \\
\hline Kelas & Frekuensi & Presentase (\%) & Frekuensi & Presentase (\%) \\
\hline $55-60$ & 11 & 33,33 & 1 & 3,030 \\
\hline $61-66$ & 5 & 15,15 & 2 & 15,15 \\
\hline $67-72$ & 9 & 27,27 & 4 & 12,12 \\
\hline $73-78$ & 4 & 12,12 & 14 & 42,42 \\
\hline $79-84$ & 4 & 12,12 & 8 & 24,24 \\
\hline $85-90$ & 0 & 00,00 & 2 & 6,060 \\
\hline $91-96$ & 0 & 00,00 & 2 & 6,060 \\
\hline Jumlah & 33 & 100 & 34 & 100 \\
\hline
\end{tabular}


Berdasarkan Tabel 3 diketahui bahwa frekuensi terbesar kelompok kontrol yaitu pada interval 55-60, berarti peserta didik yang mendapatkan nilai antara 55-60 adalah paling banyak dengan presentasi 33,33\%. Kelompok eksperimen frekuensi besar yaitu berada pada interval 73-78 dan interval 73-78, berarti peserta didik yang mendapatkan nilai antara 73-78 adalah paling banyak presentasinya yaitu sebesar 42,42\%. Untuk memperjelas distribusi hasil minat belajar pada kelas kontrol dan eksperimen disajikan histogram dengan kurva Gambar 1.

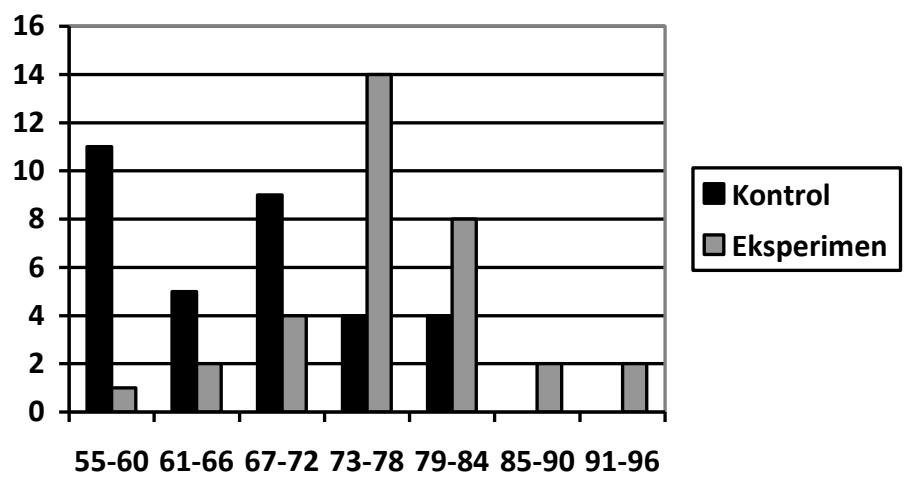

Gambar 1. Histogram Hasil Minat Belajar Kelompok Kontrol dan Eksperimen

Frekuensi terbesar kelompok kontrol pada gambar 1 yaitu pada interval 55-60, berarti peserta didik yang mendapat skor 55-60 adalah paling banyak dengan jumlah sebanyak 11 peserta didik, sedangkan pada Gambar 1 kelompok eksperimen frekuensi terbesar pada interval 73-78 sebanyak 14 peserta didik . Interval yang tidak terdapat peserta didik atau kosong pada kelompok kontrol dengan interval 85-90 dan 91-96, sedangkan kelompok eksperimen tidak ada interval yang kosong.

Pengujian persyaratan yang dilakukan dalam penelitian ini adalah uji normalitas dan uji homogenitas. Uji normalitas merupakan salah satu uji prasyarat sebelum uji independent T-test dilakukan. Uji normalitas data yang digunakan dalam penelitian ini adalah uji Kolmogorov-Smirnov yang terdapat dalam program SPSS 18. Uji normalitas dilakukan untuk mengetahui apakah sampel berasal dari populasi yang berdistribusi normal atau tidak. Jika nilai nilai atau nilai signifikansi lebih besar dari 0,05 (sig. $\geq$ 0,05 ) maka data tersebut berasal dari populasi yang berdistribusi normal sebaliknya jika lebih kecil dari 0,05 (sig. < 0,05) maka data tersebut tidak berdistribusi normal. Hasil analisis uji normalitas data menggunakan Kolmogorov-Smirnov pada software SPSS 18 disajikan pada Tabel 4.2.

Tabel 4. Hasil Normalitas Minat Belajar Peserta didik

\begin{tabular}{|l|l|l|l|l|l|}
\hline No. & $\begin{array}{c}\text { Variabel (Kolmogorov } \\
\text { Smirnov) }\end{array}$ & $\begin{array}{c}\text { Sig. Kolmogorov } \\
\text { Smirnov }\end{array}$ & Sig. & Keputusan & Kesimpulan \\
\hline 1. & $\begin{array}{l}\text { Minat belajar kontrol } \\
\text { (kelas A) }\end{array}$ & 0,094 & 0,05 & $\mathrm{H}_{0}$ diterima & Data Normal \\
\hline 2. & $\begin{array}{l}\text { Minat belajar } \\
\text { eksperimen (kelas B) }\end{array}$ & 0,657 & 0,05 & $\mathrm{H}_{0}$ diterima & Data Normal \\
\hline
\end{tabular}


Dari hasil analisis data normalitas menggunakan SPSS diperoleh signifikan sebesar 0,094>0,05 untuk minat belajar kelas kontrol sehingga dapat disimpulkan bahwa data terdistribusi normal. Dari hasil analisis data normalitas menggunakan SPSS diperoleh signifikan sebesar 0,657>0,05 untuk minat belajar kelas eksperimen sehingga dapat disimpulkan bahwa data terdistribusi normal.

Uji Homogenitas digunakan untuk mengetahui sampel terdistribusi homogen atau tidak. Uji homogenitas dilakukan menggunakan program SPSS 18. Pada hasil minat belajar signifikansi lebih dari (>) 0,05 sehingga diputuskan bahwa $\mathrm{H}_{0}$ diterima dan disimpulkan bahwa sampel berasal dari populasi yang berdistribusi homogen. Data homogenitas minat belajar disajikan dalam Tabel 5.

Tabel 5. Data Homogenitas Minat Belajar Peserta didik

\begin{tabular}{|c|c|c|c|c|}
\hline Faktor & Sig. Based on Mean & Sig. & Keputusan & Kesimpulan \\
\hline Minat belajar & 0,268 & 0,05 & $\mathrm{H}_{0}$ diterima & Homogen \\
\hline
\end{tabular}

Dari hasil analisis data homogenitas menggunakan SPSS diperoleh signifikan sebesar $0,268>0,05$ untuk minat belajar sehingga dapat disimpulkan bahwa data terdistribusi homogen. Dari perolehan pengolahan data dapat disimpulkan data terdistribusi normal dan homogeny sehingga dapat diputuskan untuk melakukan pengujian selanjutnya menggunakan uji parametric yaitu independent sample T-Test. Uji hipotesis menunakan uji T-Test Untuk menganilisis data dilakukan dengan SPSS 18. Hasil hipotesis dirangkum dalam Tabel 6.

Tabel 6. Ringkasan data Hasil Uji Hipotesis

\begin{tabular}{|c|c|c|}
\hline Hipotesis & Signifikansi Terhadap Minat Belajar Peserta didik & Keputusan \\
\hline Minat & $0,000>0,05$ & $\mathrm{H}_{0}$ ditolak \\
\hline
\end{tabular}

Hasil dari analisis data menggunakan independent sample t-test diperoleh sig. (2tailed) sebesar $0,000<0,05$ bahwa $\mathrm{H}_{0}$ ditolak dan $\mathrm{H}_{\mathrm{a}}$ diterima. Sehingga dapat diambil kesimpulan bahwa media robotik (Robot Soccer) dapat menumbuhkan minat belajar fisika peserta didik. Uji compare means merupakan uji lanjut yang dilakukan untuk mengetahui perbedaan rerata apabila pada hipotesis terdapat pengaruh yang signifikan. Uji compare means dilakukan dengan menggunakan program SPSS 18. Adapun uji compare means yang dilakukan pada hipotesis.

Tabel 7. Ringkasan Data Hasil Uji Lanjut Compare Means

\begin{tabular}{|c|c|c|c|c|c|}
\hline Minat Belajar & Mean & N & Std. deviation & Minimum & Maksimum \\
\hline Kontrol & 66,81 & 33 & 7,27 & 55 & 80 \\
\hline Eksperimen & 77,05 & 34 & 67,51 & 65 & 96 \\
\hline
\end{tabular}

Pada kelompok kontrol yang berjumlah 33 peserta didik diperoleh nilai tertinggi 80 dan nilai terendah 55 dari nilai tersebut menghasilkan rata-rata sebesar 66,81. Pada kelompok eksperimen yang berjumlah 34 peserta didik diperoleh nilai tertinggi sebesar 96 dan nilai terendah 65 dari nilai tersebut menghasilkan rata-rata sebesar 77,05. Nilai rata-rata minat belajar peserta didik pada kelompok eksperimen memiliki nilai lebih tinggi daripada peserta didik pada kelompok kontrol itu menunjukkan bahwa penggunaan media robotic (robot soccer) memberikan pengaruh pada minat belajar peserta didik. 
Ada empat faktor yang mempengaruhi peserta didik tertarik dengan pembelajaran fisika menggunakan robot. Pertama, robot merupakan media yang sedang dikembangkan saat ini sehingga peserta didik menjadi tertarik belajar fisika menggunakan robot. Penggunaan robot saat ini tidak hanya digunakan di pabrik ataupun proyek-proyek besar, tetapi penggunaan robot sudah dikembangkan lagi menjadi robot yang mampu membantu pekerjaan manusia sehari-hari contohnya saja seperti robot asisten rumah tangga yang bisa menggatikan tugas Asisten Rumah Tangga (ART). Robot pelayan toko yang mampu melayani pembeli toko ketika berbelanja.

Kedua, peserta didik tertarik dengan pembelajaran langsung sehingga memudahkan peserta didik untuk memahami materi. Pada pembelajaran fisika menggunakan robot peserta didik juga diajarkan untuk praktek langsung merangkai robot. Pada saat praktek merangkai robot peserta didik sangan antusias dalam pembelajaran, dengan praktek secara langsung merangkai robot dapat memberikan pembelajaran yang bermakna. Pada penelitian yang dilakukan Wijaya (2015) bahwa dengan mengikuti lomba robotika dapat dengan baik meningkatkan minat belajar peserta didik SMK Negeri 2 Singosari.

Ketiga, pembelajaran fisika menggunakan robot merupakan bukti nyata dari aplikasi ilmu fisika. Fisika yang biasanya hanya disajikan dengan menggunakan tampilan soal dan rumus saja membuat peserta didik menjadi tidak berminat untuk belajar fisika. Pembelajaran fisika yang dikemas dengan menggunakan robot membuat peserta didik menjadi berminat untuk belajar fisika. Dengan menggunakan robot membuat peserta didik menjadi mudah untuk mempelajari fisika yang bersifat abstrak. Pada penelitian media robot transporter dalam proses kegiatan belajar mengajar bisa terlaksana dengan baik. Dapat disimpulkan bahwa pembelajaran menggunakan robot memberikan pengaruh yang positif bagi peserta didik dari segi minat, hasil belajar dan kemampuan berpikir.(Ardi, Munoto, \& Buditjahjanto, 2017).

Keempat, pembelajaran menggunakan robot memberikan daya Tarik tersendiri bagi peserta didik karena baru pertama kali mereka mendapat pembelajaran menggunakan robot. Penggunaan robot sebagai media pembelajaran merupakan salah satu inovasi untuk menarik minat belajar peserta didik. Minat yang muncul ini akan meningkatkan kebiasaan belajar kearah positif (Flora Siagian, 2015). Jatmiko (2010) berpendapat bahwa salah satu penghambat perkembangan robotika di Indonesia adalah biaya untuk alat-alat robot tergolong mahal. Sehingga, penerapan pembelajaran robotic di sekolah jarang digunakan. Jika pemerintahan Indonesia memasukkan robot menjadi salah satu mata pelajaran wajib di sekolah tentu akan memberikan dampak yang positif untuk kemajuan pendidikan di Indonesia. Indonesia akan mampu bersaing dengan negaranegara maju lainnya seperti Amerika dan Jepang. Pada saat ini pun negara-negara maju sedang mengembangkan robot untuk meningatkan kualitas hidup manusia. Dengan mengenalkan robot pada peserta didik sejak berada di bangku sekolah memiliki tujuan besar kelak peserta didik tersebut mampu mengembangkan robot di Indonesia pada masa yang akan datang, sehingga kita dapat bersaing dengan bangsa-bangsa lain yang sekarang ini sedang mengembangkan robot.

\section{SIMPULAN DAN SARAN}

Robotik merupakan media yang saat ini sedang dikembangkan untuk memudahkan pekerjaan manusia. Selain untuk memudahkan pekerjaan manusia robot digunakan juga untuk membantu proses belajar mengajar disekolah. Pada penelitian ini diperoleh hasil bahwa media robotic menggunakan robot soccer mampu meningkatkan minat belajar peserta didik. Robot soccer merupakan robot yang dibuat untuk bisa melakukan permainan sepak bola layaknya pemain bola. Robot yang dibuat untuk dapat 
menjalankan perintah menggunakan remot control. Hasil pengolahan data nilai pretes diperoleh rata-rata sebesar 66,81 , sedangkan pada hasil posttest diperoleh nilai rata-rata sebesar 77,05 menunjukkan bahwa penggunaan media robotic berpengaruh meningkatkan minat belajar peserta didik pada mata pelajaran fisika. Media robotik (robot soccer) dapat menjadi alternatif media pembelajaran di sekolah untuk guru fisika. Untuk tingkatan kesulitan perangkaian robot harus diperhatikan, dengan melihat kemampuan peserta didik dari jenjang SD, SMP dan SMA. Penggunaan media robotik (robot soccer) dapat dikembangkan menggunakan kontrol sensor inframerah atau bluetooth sehingga tidak perlu menggunakan remot kontrol. Pengembangan media robotik harus tetap dilakukan untuk meningkatkan kualitas robot tersebut dan semakin baik digunakan untuk sistem pembelajaran di sekolah.

\section{DAFTAR PUSTAKA}

Ardi, P., Munoto, M., \& Buditjahjanto, A. (2017). Pengembangan Media Pembelajaran Robot Transporter Pada Mata Kuliah Elektromekanik S1 Pendidikan Teknik Elektro IKIP PGRI Madiun. Jupiter (Jurnal Pendidikan Teknik Elektro), 2(1), 8.

Ardiansyah, T. W. (2019). Pengembangan Panduan Pembuatan Line Follower Analog Berbasis Scaffolding Sebagai Media Pembelajaran Elektronika Dasar di SMK. Jurnal Pendidikan, 2(1), 58-64.

Astuti, A. Y., \& Sugianti, S. (2019). Workshop Pembelajaran Teknologi Multimedia untuk Guru SDN 4 Cepoko Kecamatan Ngrayun Guna Pengembangan Bahan Ajar. Jurnal ADIMAS, 3(1), 46-50.

Dewi, L. S., Nyeneng, I. D. P., \& Suana, W. (2019). Development of Student Worksheets on Heat Material Based on Guided Inquiry to Increase Creative Thinking Skills Pengembangan LKS Materi Kalor dengan Model Inkuiri Terbimbing untuk Meningkatkan Keterampilan Berpikir Kreatif Siswa. Kasuari: Physics Education Journal ( KPEJ ), 2(2), 110-120.

Efendi, A. (2018). Pengembangan Media “Agus Trainer” Untuk Pembelajaran Robotika. Jurnal Ilmiah Edutic, 5(1), 32-38.

Flora, S, R. E. (2015). Pengaruh Minat dan Kebiasaan Belajar Siswa terhadap Prestasi Belajar Matematika. Formatif: Jurnal Ilmiah Pendidikan MIPA, 2(2), 122-131.

Nurhasanah, S., \& Sobandi, A. (2016). Minat Belajar Sebagai Determinan Hasil Belajar Siswa (Learning Interest as Determinant Student Learning Outcomes). Jurnal Pendidikan Manajemen Perkantoran, 1(1), 128-135.

Putra, I. Y., Sigalingging, S. F., \& Saraswati, D. L. (2018). Penentuan ketinggian dan kecepatan minimum benda pada track melingkar vertikal. Jurnal Riset Dan Kajian Pendidikan Fisika, 5(1), 46.

Putri, D. A., \& Saraswati, D. L. (2018). Architecture of Atwood Machine Props with Sensor-based Passive Infrared. Indonesian Review of Physics, 1(M), 15-18.

Ramansyah, W., \& Brian, T. (2018). Pengembangan Multimedia Pembelajaran Interaktif Berbasis Appypie pada Bahasan Pengenalan Robotika Dasar. Prosiding Seminar Nasional Pendidikan Kaluni, 1(April), 72-79.

Saraswati, D. L. (2018). Student Worksheet Based Inkuiri Social Interactions. Journal of Physics: Conference Series, 1120(1).

Saraswati, D. L., \& Ishafit, I. (2015). Penggunaan Cooperative Learning Tipe Numbered Heads Together (NHT) untuk Meningkatkan Motivasi dan Prestasi Hasil Belajar Siswa Smp. Jurnal Pendidikan Fisika, 3(1).

Widyaningsih, S. W., \& Yusuf, I. (2018). Project Based Learning Model Based on Simple Teaching Tools and Critical Thinking Skills. Kasuari: Physics Education 
Journal (KPEJ), 1(1), 12-21.

Yulianto, A., \& Handoyo, H. P. (2012). Penerapan Behavior-Based Control dan Fuzzy Logic Controller pada Sistem Navigasi Robot Soccer. CENTRE Civil and Electrical Engineering Journal, 7(1), 16-23.

Jatmiko. (2010). Perancangan Pembuatan Website Sebagai Media Informasi dan Promosi Pada mall puri indah. Graha ilmu. Yogyakarta.

Loekmono. (2004). Belajar Bagaimana Belajar. Jakarta: BPK Gunung Mulia.

Sudarmono. (1994). Tuntunan Metodologi Belajar. Jakarta: Grasindo. 